\title{
Preservation and evolution of organic matter during experimental fossilisation of the hyperthermophilic Archaea
}

\section{Methanocaldococcus jannaschii}

François Orange, Jean-Robert Disnar, Pascale Gautret, Frances Westall, Nadège Bienvenu, Nathalie Lottier, Daniel Prieur

\section{Short title}

Preservation of organic matter during experimental fossilisation

\section{Affiliations}

F. Orange, F. Westall :

- Centre de Biophysique Moléculaire - UPR 4301, CNRS, Rue Charles Sadron, 45071 Orléans Cedex 2, France

- Observatoire des Sciences de l'Univers en région Centre - UMS 3116, 1A Rue de la Férollerie, 45071 Orléans Cedex 2, France

e-mail : francois.orange@gmail.com

F. Orange, J. R. Disnar, P. Gautret, N. Lottier :

- Univ d'Orléans, ISTO, UMR 7327, 45071, Orléans, France ; CNRS/INSU, ISTO, UMR 7327, 45071 Orléans, France ; BRGM, ISTO, UMR 7327, BP 36009, 45060 Orléans, France.

N. Bienvenu, D. Prieur :

- Université de Bretagne Occidentale, Institut Universitaire Européen de la Mer UMR 6197, Technopôle Brest Iroise, Rue Dumont d'Urville, 29280 Plouzané, France. 


\section{Keywords}

Archaea, Methanocaldococcus jannaschii, fossilisation, amino acids, monosaccharides, fatty acids 


\section{Abstract}

Identification of the earliest traces of life is made difficult by the scarcity of the preserved microbial remains and by the alteration and potential contamination of the organic matter (OM) content of rocks. These factors can confuse interpretations of the biogenicity and syngenicity of fossilised structures and organic molecules found in ancient rocks. In order to improve our knowledge of the fossilisation processes and their effects at the molecular level, we made a preliminary study of the fate of OM during experimental fossilisation. Changes in the composition and quantity of amino acids, monosaccharides and fatty acids were followed with HPLC, GC and GC-MS analyses during one year of silicification of the hyperthermophilic Archaea Methanocaldococcus jannaschii. Although the cells themselves did not fossilise and the accompanying extracellular polymeric substances (EPS) did, our analyses showed that the OM initially present in both cells and EPS was uniformly preserved in the precipitated silica, with amino acids and fatty acids being the best preserved compounds. This study thus completes previous data obtained by electron microscopy investigations of simulated microbial fossilisation and can help better identification and interpretation of microbial biosignatures in both ancient rocks and in recent hydrothermal formations and sediments.

\section{Introduction}

Traces of ancient life in rocks occur as fossilised remains of microorganisms, their communities and biostructures, as degraded organic compounds derived from original biological components, or as isotopic signatures (e.g. Brocks and Pearson 2005 and references therein; Westall 2011; Westall and Cavalazzi 2011). When it comes to investigations of the most ancient traces of life, the search is complicated by the limited preservation of ancient rocks in terms of quantity and metamorphic grade. The oldest known sedimentary rocks occur in the Barberton Greenstone Belt (South Africa, 3.2-3.5 Ga), the Pilbara Craton (NW Australia, 3.3-3.5 Ga) and the Isua and Akilia Greenstone Belts (Greenland, 3.73.8 Ga). Only those in Barberton and the Pilbara are of low enough metamorphic grade to be useful for in depth investigation of biosignatures. The oldest traces of life identified in these rocks (3.5-3.8 Ga) comprise silicified microfossils in the form of colonies, microbial mats and stromatolites that probably included chemotrophic and possibly anoxygenic photosynthetic microorganisms (Walsh 1992, 2004; Tice and Lowe 2004, 2007; Allwood et al. 2006, 2009; Westall and Southam 2006; Westall et al. 2006a,b, 2011; Westall 2011). However, due to the 
degradation sustained by these biosignatures and the possibility of a contamination by non-syngenetic OM (Brocks 2011), numerous debates have arisen concerning the biogenicity of observed structures (e.g. Apex Chert: Schopf (1993) and Brasier et al. (2002); Isua: Pflug and Jaeschke-Boyer et al. (1979) and Westall and Folk (2003), Mojzsis et al. (1996) and van Zuilen et al. (2002)). These debates have highlighted the difficulty of identifying physical structures as well as molecules preserved in ancient rocks as traces of life, and our lack of knowledge concerning the fossilisation processes that lead to the long-term preservation of biosignatures and, especially, of their most fragile cellular/organic components.

This article is part of a broader study of the preservation of the kinds of microorganisms that could have lived under the extreme environmental conditions of the early Earth, such as the deep-sea hyperthermophilic methanogenic Archaea Methanocaldococcus jannaschii (Jones et al. 1983), through experimental fossilisation. Previous experiments to fossilise microorganisms had been successfully applied to a wide range of species, including Cyanobacteria (Oehler and Schopf 1971; Oehler 1976; Francis et al. 1978; Phoenix et al. 2000; Benning et al. 2004a, 2004b), diverse marine microbes (Westall et al. 1995), Gram-positive (Ferris et al. 1988; Westall 1997) and -negative Bacteria (Birnbaum et al. 1989; Westall et al. 1995 ; Westall 1997; Toporski et al. 2002; Lalonde et al. 2005), and Archaea (Orange et al. 2009, 2011). They provided important information for the understanding of the fossilisation processes. In particular, in two previous studies (Orange et al. 2009, 2011) we investigated the mechanisms of fossilisation of Archaea in saturated silica solutions and the preservation of morphological structures by electron microscopy monitoring. In one species, most of the cells of M. jannaschii lysed naturally within a week after the beginning of the experiment despite the rapid formation of a silica precipitate (Orange et al. 2009). Only a few significantly deformed cells and cell remains were still present after 1 month of fossilisation and they lost all their recognisable features as the fossilisation continued over the period of a year. However, a significant amount of extracellular polymeric substances (EPS) was fossilised and preserved. This study is the first reported case of an experimental fossilisation that did not lead to the preservation of the cells and it underlines the importance of heterogeneous cell preservation in the rock record. 
In this particular context, we wanted to investigate the processes that take place during the experimental fossilisation of $M$. jannaschii in more detail through the monitoring of progressive changes in the OM. The particular unfolding of this fossilisation seemed to us more interesting and worthwhile to obtain information on the changes in the $\mathrm{OM}$ compositions during fossilisation, since the actual physical preservation of cells in the rock record is less common than the preservation of the organic remnants of the cells. More precisely, our objectives were to verify the impact of silicification at the molecular level, through a yearlong monitoring of the most common and most labile organic compounds of $M$. jannaschii cells and EPS (amino-acids, monosaccharides, fatty acids) and to provide a first insight into the preservation of the OM during silicification at the molecular level. This was particularly important given that, in this case, these biological compounds were not directly protected by efficient fossilisation of the cellular structures.

\section{Materials and Methods}

\section{Cell growth}

Pure cultures of M. jannaschii were provided by the Laboratoire de Microbiologie des Environnements Extrêmes, Plouzané, France. M. jannaschii was cultured in an autotrophic medium. The medium contained (per litre of distilled water) $25 \mathrm{~g}$ of NaCl, $3 \mathrm{~g}$ of $\mathrm{MgCl}_{2}, 1 \mathrm{~g}$ of $\mathrm{NH}_{4} \mathrm{Cl}, 0.15 \mathrm{~g}$ of $\mathrm{CaCl}_{2}, 0.5 \mathrm{~g}$ of $\mathrm{KCl}, 0.3 \mathrm{~g}$ of $\mathrm{KH}_{2} \mathrm{PO}_{4}$ and $0.001 \mathrm{~g}$ of resazurin (as an anaerobic indicator). The $\mathrm{pH}$ was adjusted to 6.5 and the medium was sterilised by autoclaving. $500 \mathrm{~mL}$ of medium were dispensed into $1 \mathrm{~L}$ sterile bottles. Anaerobiosis was obtained by first applying vacuum to the bottle and then saturating it with $\mathrm{N}_{2}$ (Balch and Wolfe 1976). The $\mathrm{N}_{2}$ atmosphere was then replaced by a $\mathrm{H}_{2} / \mathrm{CO}_{2}$ atmosphere (80:20; $300 \mathrm{kPa})$. The medium was finally reduced by adding $5 \mathrm{~mL}$ of a sterile $10 \%$ (wt/vol) solution of $\mathrm{Na}_{2} \mathrm{~S} .9 \mathrm{H}_{2} \mathrm{O}$ to each vial. The medium, inoculated to a final concentration of $1 \%$, was incubated at $80{ }^{\circ} \mathrm{C}$ with shaking. Microbial growth was monitored with a phase-contrast microscope (Olympus CX 40). 


\section{Experimental fossilisation}

The silicification procedure is derived from the methods used for previous silicification experiments (Birnbaum et al. 1989; Toporski et al. 2002), and is identical to that used by Orange et al. (2009).

Silicification was launched at the end of the exponential growth phase of the microorganisms. As a silicifying agent, we used a commercially available pure sodium silicate solution (Riedel de Haën) containing $27 \% \mathrm{SiO}_{2}$ and $\sim 10 \%$ $\mathrm{NaOH}$. This pure solution was diluted 10 times to make a stock solution and filtered using a $0.2 \mu \mathrm{m}$ polycarbonate Millipore filter for sterilisation and to remove particulate material. $9 \mathrm{~mL}$ of this stock solution were injected into each vial to obtain a final approximate silica concentration of $350 \mathrm{ppm} \mathrm{Si}$. The injection of silica into the microbial cultures marked the start or 'zero time' of the silicification. Spontaneous polymerisation of silica occurred within a few hours after the injection of silica, leading to the formation of a white precipitate of colloidal amorphous silica at the bottom of the flasks. Separate bottles were prepared for silicification times of 24 hours to 1 year. After the silica injection, each vial was placed in an oven at $60{ }^{\circ} \mathrm{C}$ until sampled. The bottles remained sealed in anaerobic and contamination-free conditions until sampled.

\section{Lyophilisation}

At the end of each fossilisation period, the $500 \mathrm{~mL}$ cultures were centrifuged (Sorvall, SLA-1500 rotor, $7000 \mathrm{~g}, 20 \mathrm{~min}$ ). For the purpose of lyophilisation, the silica/cell pellet was collected, along with $\sim 50 \mathrm{~mL}$ of culture medium (the rest was discarded; thus only a small part of the EPS dissolved in the medium was kept). The silica/cell pellet was thereafter frozen at $-80^{\circ} \mathrm{C}$ before being lyophilised. A $M$. jannaschii cell pellet, collected from a fresh culture with no silica added, was also lyophilised this way. After one year of fossilisation, the silica/cell pellet at the bottom of the culture bottles formed a very dense precipitate, which was lyophilised as described above. In addition, for this sample, a part of the medium was also kept and lyophilised for separate analysis. Although the microbial cultures had a volume of $500 \mathrm{~mL}$, the amount of dried samples recovered after lyophilisation was always low, which prevented us from making 
systematic replicates of the OM analyses. Instead, punctual replicates were made for each categories of organic compounds analysed.

\section{EPS extraction}

In addition to monitoring the experimental fossilisation made on lyophilised samples, the EPS and cells in a fresh M. jannaschii culture were separated in order to identify specific compounds and to follow their evolution during the experimental fossilisation. The EPS were recovered and purified using the cold ethanol extraction method (Antón et al. 1988; Underwood et al. 1995; Decho et al. 2005; Klock et al. 2007). A 500 mL M. jannaschii culture was centrifuged ( 2 hours, $20000 \mathrm{~g}$ ). The pellet, hereafter called "cell" fraction and containing cells and some cell-bound EPS, was recovered. The dissolved EPS contained in the supernatant (hereafter called "EPS" fraction) were precipitated and recovered using the following procedure. $\mathrm{NaCl}$ was added to the supernatant to a final concentration of $20 \mathrm{~g} / \mathrm{L}$. The samples were kept at $4{ }^{\circ} \mathrm{C}$ to allow precipitation and decantation of the EPS. The latter were finally recovered by centrifugation $(5000 \mathrm{~g}$ ) and rinsed in successive ethanol baths (from $70 \%$ to 100 $\%$ aqueous ethanol). The same rinsing procedure was applied to the "cell" fraction. The "EPS" and "cell" fractions were kept in absolute ethanol at $4{ }^{\circ} \mathrm{C}$ until used.

To evaluate the presence of organic materials (e.g. EPS) in the silica precipitate that formed after the silica injection, a control experiment was performed where the silica was injected in a medium of a fresh $M$. jannaschii culture after having removed the cells by centrifugation ( 2 hours, 20000g). The silica precipitate was collected after 24 hours and fixed with $2.5 \%$ glutaraldehyde. The sample was then prepared for scanning electron microscopy (SEM) observation with the critical point drying method using the procedure described in Orange et al. (2009). SEM observations and analyses were carried with a Hitachi S-4500 Field Emission Gun SEM equipped with a EDX detector (Oxford Instruments). 


\section{Amino acid analyses}

Amino acid (AA) compositions of the samples were determined by Thermo-Spectra High Pressure Liquid Chromatography (HPLC) after acid hydrolysis and phenylisothiocyanate (PITC) derivatisation, with the method used by Gautret and Trichet (2005). For the analyses, $~ 30 \mathrm{mg}$ of lyophilised samples were used. $400 \mu \mathrm{L}$ of the "cell" fraction and $1 \mathrm{~mL}$ of the "EPS" fraction in absolute ethanol were collected and air dried. Due to the very small amount of material, it was not possible to determine the precise dry weight of these fractions used for this analysis $(\sim 1 \mathrm{mg})$. Hydrolysis was performed in $6 \mathrm{~N} \mathrm{HCl}$ at $110^{\circ} \mathrm{C}$ for 24 hours in sealed tubes under a $\mathrm{N}_{2}$ atmosphere to prevent oxidation. The samples were neutralised by adding $200 \mu \mathrm{l}$ of a $\mathrm{ddH}_{2} \mathrm{O} /$ methanol/triethylamine mixture (proportions 1:1:1 v/v/v) and then dried in a SpeedVac. The samples were derivatised for 20 minutes by phenylisothiocyanate (PITC) by adding, in each sample, $20 \mu \mathrm{L}$ of a stock solution of methanol/triethylamine/dd $\mathrm{H}_{2} \mathrm{O} / \mathrm{PITC}$ (proportions: 140, 20, 20 and $20 \mu \mathrm{L}$, respectively). The samples were analysed by reverse phase chromatography using a Thermo Finnigan HPLC equipped with a Hypersil ODS C18 $5 \mu \mathrm{m}$ column with an acetonitrile gradient (Eluent A: $0.8 \mathrm{~mL}$ of orthophosphoric acid per liter of ultrapure water, $\mathrm{pH}$ adjusted to 7.6 by addition of 30\% NaOH solution; Eluent B: 50\% eluent A / 50\% acetonitrile; 1 hour gradient from $2 \%$ of Eluent B as the chromatographic starting condition to $50 \%$, followed by a short $80 \%$ cleaning phase and equilibration back to the starting condition; flow rate: $1 \mathrm{~mL} / \mathrm{min}$; injection volume: $20 \mu \mathrm{L}$ ). The molecular composition was determined by calculating peak areas from the analysed compounds compared with a standard (STP : "Amino-acid standard for hydrolyse analysis", Beckman System 7300/6300). The total mass of the soluble proteinic compounds (in $\mu \mathrm{g}$ per $\mathrm{g}$ of dried sample) was obtained by adding the individual masses of all the analysed AAs. Due to a permanent contamination peak, arginine could not be quantified in the lyophilised samples but was measured in samples kept in absolute ethanol ("cell" and "EPS" fraction) (Table 1). Error bars were determined for each individual amino acid on the basis of 3 analyses of standard solutions prepared at 3 different concentrations. Errors thus differ for each AA. 


\section{Monosaccharide analysis}

The monosaccharide composition was measured using gas chromatography (GC) after moderate acid hydrolysis $\left(1.2 \mathrm{M} \mathrm{H}_{2} \mathrm{SO}_{4}\right)$ and silylation (Comont et al. 2006, Disnar et al. 2008). Approximately $150 \mathrm{mg}$ of lyophilised sample were used for the analyses. Moderate acid hydrolysis was performed with $2.5 \mathrm{~mL}$ of $1.2 \mathrm{M} \mathrm{H}_{2} \mathrm{SO}_{4}$ at $100^{\circ} \mathrm{C}$ for 3 hours, under vacuum. 6deoxy D-glucose was used as an internal standard (Wicks et al. 1991). The samples were subsequently neutralised with solid $\mathrm{CaCO}_{3}$. The precipitate was removed by centrifugation and the supernatant was evaporated to dryness before being redissolved in $0.5 \mathrm{~mL}$ of a $0.2 \%(\mathrm{~m} / \mathrm{v}) \mathrm{LiClO}_{4} /$ pyridine solution (Bethge et al. 1966; Ogier et al. 2001). Samples were once again centrifuged, and the supernatant was placed in an oven at $60^{\circ} \mathrm{C}$ overnight in sealed vials. Finally, $100 \mu \mathrm{L}$ of a mixture of Trisyl (N,O-Bis-(trimethylsilyl)-trifluoroacetamide (BSTFA) + trimethylchlorosilane (TMCS); Sigma) was added and the samples were heated at $60^{\circ} \mathrm{C}$ for 1 hour in sealed and pre-ashed vials, before GC analysis. Monosaccharide analysis was performed by gas chromatography with a Auto System XL (Perkin-Elmer) equipped with a $25 \mathrm{~m} \times 0.32 \mathrm{~mm}$ i.d. CP-Sil 5CB capillary column $(0.25 \mu \mathrm{m}$ film thickness) and a flame ionisation detector (FID). Helium was used as a carrier gas. After splitless injection at $240^{\circ} \mathrm{C}$, analyses were performed in the following conditions : oven temperature kept at $60^{\circ} \mathrm{C}$ for 1 minute, then raised to $120^{\circ} \mathrm{C}$ at $30^{\circ} \mathrm{C} \cdot \mathrm{min}^{-1}$, and finally to $240^{\circ} \mathrm{C}$ at $3{ }^{\circ} \mathrm{C} \cdot \mathrm{min}^{-1}$ at which it was maintained for 30 minutes. A mixture of eight monosaccharides (ribose, arabinose, xylose, rhamnose, fucose, glucose, mannose and galactose) was used as external standard (i) for compound identification (through peak retention times), (ii) for individual response coefficient determination and (iii) for quantification of the different analysed compounds, and by comparison with the internal standard (6-deoxy D-glucose). Replicates analyses gave an analytical precision better than 15\% (Comont et al. 2006; Disnar et al., 2008).

\section{Fatty acid analyses}

Prior to GC-MS analysis, fatty acids (FA) were released following two distinct procedures: thermochemolysis with tetramethylamonium hydroxide (TMAH, Disnar et al. 2008), and acid hydrolysis (Stefanova and Disnar 2000). 
The first of these two procedures convert the FAs into methyl esters and the second one into free acids. The latter are esterified prior to analysis (details in Stefanova and Disnar 2000). Approximately $150 \mathrm{mg}$ of lyophilised sample were used. As for the AA analyses, $400 \mu \mathrm{L}$ and $1 \mathrm{~mL}$ of the "cell" and "EPS" fractions, respectively, were also collected and evaporated.

For thermochemolysis, a mixture of a TMAH solution (10\% in $\mathrm{MeOH})$, internal standard (heptylbenzoic acid dissolved in $\mathrm{MeOH}$ ), and methanol (proportions 2:1:2(v/v/v); 1:1:2 for the "cell" and "EPS" fractions) was added to the samples in test tubes, which were subsequently sealed and heated at $70^{\circ} \mathrm{C}$ for 1 hour. Vacuum was made in the tubes to prevent oxidation, and their bottom extremity was placed for 20 minutes in a sand bath heated at $250^{\circ} \mathrm{C}$. After cooling, the products were extracted with $1 \mathrm{~mL}$ of ether. The ether solutions were transferred into vials, and evaporated until dryness at room temperature under a fumehood. The samples were then dissolved in dichloromethane, before being analysed by GC-MS.

For the acid hydrolysis, a mixture of a $6 \mathrm{~N} \mathrm{HCl}$ solution and methanol (proportions 1:1 v/v) was added to the samples in test-tubes along with the internal standard ( $5 \alpha$-cholestane in $\mathrm{MeOH})$. The tubes were heated overnight in a water bath at $100^{\circ} \mathrm{C}$. Afterwards, the samples were placed in a separation funnel with a few $\mathrm{mL}$ of ether. The ether fraction was recovered and evaporated. The samples were then dissolved in anhydrous methanol with a few drops of acetyl chloride and evaporated to dryness at $80^{\circ} \mathrm{C}$ for 2 hours. Finally, the samples were dissolved in dichloromethane, before GC-MS analysis.

Lipid analyses were performed by GC-MS on a TRACE-Polaris GCQ. The gas chromatograph was fitted with a Rtx-5MS capillary column $(30 \mathrm{~m}, 0.25 \mathrm{~mm}$ i.d., $0.25 \mu \mathrm{m}$ film thickness). The GC operating conditions were: temperature held at $40^{\circ} \mathrm{C}$ for $1 \mathrm{~min}$, then increased from 40 to $120^{\circ} \mathrm{C}$ at $30^{\circ} \mathrm{C} \cdot \mathrm{min}^{-1}, 120$ to $240^{\circ} \mathrm{C}$ at $5^{\circ} \mathrm{C} \cdot \mathrm{min}^{-1}$, with final isothermal hold at $240^{\circ} \mathrm{C}$ over $30 \mathrm{~min}$. The sample was injected splitless, with the injector temperature set at $280^{\circ} \mathrm{C}$. The carrier gas was helium. The mass spectrometer was operated in the electron ionisation (EI) mode at $70 \mathrm{eV}$ ionisation energy and scanned from 50 to $600 \mathrm{Da}$. Compounds were identified by using their retention time and their mass spectra. Quantification was made using the internal standard. Error margins were calculated from replicates analyses. 


\section{Results}

Table 1 shows the analysis results for AAs, monosaccharides and FAs.

\section{Amino acid analyses}

Fresh M. jannaschii cultures contain more dicarboxylic (Asp, Glu) than basic AAs (Lys, His) (Fig. 1a). The amounts of neutral AAs (Gly, Ala, Val, Leu, Ile) are also significant, with slightly more of the smallest ones (Gly, Ala, Val), as well as proline (Pro). AA compositions of the "cell" and "EPS" fractions showed some differences. The "cell" fraction contained a relatively large amount of charged (Asp, Glu, His, Lys, Arg; 48.3\%) and non-polar AAs (Ala, Ile, Leu, Val, Phe, Pro; 43.7\%) and a low content of polar AAs (Cys, Ser, Thr, Tyr ; 8.0\%) (Fig. 1a, Table 1). In comparison, the "EPS" fraction was characterised by a majority of non-polar AAs (71.0 \%) and low amounts of dicarboxylic AAs (Asp, Glu; $7.5 \%$, vs. $34.2 \%$ for the "cell" fraction). The AA composition of the whole lyophilised M. jannaschii culture appeared logically as a mean of the "cell" and "EPS" compositions (Fig. 1a).

24 hours after the injection of the silica solution in the culture, the total amount of analysed AAs was three times higher in the freshly formed precipitate than in the fresh culture (Fig. 1b), probably as a consequence of the formation of this precipitate, which had fixed EPS originally dissolved in the medium (see Discussion). Afterwards, this amount decreased progressively in the first month of fossilisation to reach the fresh culture value. After one year, the total amount analysed was slightly higher than the fresh culture amount. The two months value was also significantly higher (see Discussion). Figs $1 \mathrm{c}, 1 \mathrm{~d}, 1 \mathrm{e}$ and $1 \mathrm{f}$ show the evolution of the percentage of individual AAs during the experimental fossilisation, sorted by types. Basic and dicarboxylic AAs show opposite trends (Figs. 1c, 1d). Apart from glycine and serine, neutral and other AA proportions did not change significantly during the experiment (Figs 1e, 1f). The analyses made after one year of fossilisation showed that there was still a large amount of 
AAs remaining in the dense silica precipitate, as well as in the medium (Fig. 1g). While the total amount of AAs in the silica precipitate after one year was twice the amount measured in the fresh culture (Fig. 1b; Table 1), the initial and final AA compositions were similar (Fig. 1h).

\section{Monosaccharide analyses}

The analysis of a fresh $M$. jannaschii culture showed the presence of four aldohexoses: mannose, allose, galactose and glucose (Table 1). Glucose was the most abundant compound ( $\sim 80 \%$ of the total monosaccharides analysed). According to the chromatograms, no other peaks related to other compounds were present. Due to the small amounts of samples available, individual analyses of the "cell" and "EPS" fractions failed to give relevant results.

Only glucose and mannose could be followed in the silica precipitate during the whole fossilisation, the former being always much more abundant than the latter (Table 1; Fig. 2b). The other monosaccharides were not identified in the fossilised samples, apart from traces of allose after one month (Table 1). Similar to the AAs, the total amount of analysed monosaccharides in the silica precipitate was twice as high as in the fresh culture 24 hours after the injection of silica in $M$. jannaschii cultures (see Discussion). This amount decreased strongly after 1 month and remained constant afterwards (Fig. 2a). For the individual monosaccharide compositions, while the quantity of glucose remained stable after one month, mannose progressively disappeared and was not detected after one year (Fig. 2b). The final glucose quantity in the precipitate was only about one third of the fresh culture value (Table 1, Fig. 2b).

\section{Fatty acid analyses}

Thermochemolysis with TMAH allowed the identification of a wide range of FAs in the fresh M. jannaschii culture from $n-\mathrm{C}_{12: 0}$ to $n$ - $\mathrm{C}_{22: 0}$ (Fig. 3a). We noticed the expected predominance of compounds with an even carbon number and, in particular, high amounts of $n-\mathrm{C}_{16: 0}$ and $n-\mathrm{C}_{18: 0}$ which together represented almost $60 \%$ of the total analysed (Table 1). There were also significant amounts of $n-\mathrm{C}_{20: 0}$ and $n-\mathrm{C}_{22: 0}$. Acid hydrolysis allowed detection of a wider range of FAs, 
up to $n-\mathrm{C}_{30: 0}$, as well as compounds that were not seen after thermochemolysis (e.g. $n$ - $\mathrm{C}_{19: 0}$ ) (Fig. 3a). As in the preceding analysis, the even over odd carbon number compound predominance was the rule. $n-\mathrm{C}_{16: 0}$ and $n-\mathrm{C}_{18: 0}$ represented 70 $\%$ of the total FAs analysed (Fig. 3a, Table 1). The other FAs were usually only found in small quantities $(<5 \%)$. Thermochemolysis performed on "cell" and "EPS" fractions showed only minor compositional differences (Fig. 3b) with a distribution of FAs similar to that analysed in the whole culture.

Generally, the total amounts of FAs released were similar for the two extraction methods (Table 1, Fig. 3c). As for the AAs and monosaccharides, both methods showed a significant increase of the quantities analysed in the silica precipitate after 24 hours of fossilisation, followed by a quick decrease. After one week, the total amounts analysed seemed to stabilise above the fresh culture value for the TMAH extraction. The results of the acid hydrolysis extraction also showed an important increase after 2 months.

Monitoring of the FA composition during the fossilisation was limited to thermochemolysis, which gave the most reproducible results. After 24 hours of fossilisation, the amounts of FAs extracted in this way were ten times greater than those found in the fresh culture (Fig. 3c). This was accompanied by an increase in the proportions of the two main FAs identified $\left(n-\mathrm{C}_{16: 0}\right.$ and $\left.n-\mathrm{C}_{18: 0}\right)$ and a depletion in the larger compounds $\left(n-\mathrm{C}_{20: 0}\right.$ and $n$-C $\left.\mathrm{C}_{22: 0}\right)$ (Fig. $\left.3 \mathrm{~d}\right)$. Only the two most abundant compounds ( $n-\mathrm{C}_{16: 0}$ and $n-\mathrm{C}_{18: 0}$ ) could be monitored satisfactorily during the fossilisation (Fig. 3e). Since the analysed quantities of the other compounds was low and the peaks formed were small, it was difficult to follow their evolution during the fossilisation. After 24 hours, $n$ - $\mathrm{C}_{18: 0}$ quantities decreased quickly before stabilising until the end of the experiment, while $n-\mathrm{C}_{16: 0}$ decreased more slowly after one month (Fig. 3e). After one year, only a few light FAs $(\leq n-$ $\mathrm{C}_{16: 0}$ ) remained in the aqueous medium (Table 1) and those in the silica precipitate had the same distribution (Fig. 3f). The FAs extracted by acid hydrolysis in the fresh culture and in the silica precipitate after one year of fossilisation were similar (Fig. 3h), with similar total analysed masses in the two samples (Fig. 3c). This was not the case for the FAs extracted by thermochemolysis (Fig. 3g), which showed a final enrichment in $n-\mathrm{C}_{14: 0}$ and $n-\mathrm{C}_{16: 0}$, and the absence of the largest compounds $\left(n-\mathrm{C}_{20: 0}, n-\mathrm{C}_{22: 0}\right)$, with total masses three times higher than in the fresh culture (Fig. 3c). 


\section{Discussion}

This study represents a first attempt to monitor the degradation and preservation of the microbial OM during a one-year fossilisation experiment. The similarity between the AA composition of the fresh culture and the sample fossilised for one year (Fig. 1h) demonstrates consistency in the measurements and indicates that these AA analyses were not biased by the presence of silica. For the FAs, the use of an internal standard introduced at the start of the analysis was a guarantee of the reliability of the results. The two methods used to analyse these compounds (thermochemolysis and acid hydrolysis) theoretically release FAs involved in different chemical combinations (saponifiable amides, and hydrolysable esters, respectively; Stefanova and Disnar 2000, and references therein), giving complementary results. Moreover, both methods used could also detect free FAs (initially, or liberated during fossilisation).

Although replicate analyses could not be made on a systematic basis, the reliability of the measurements is also supported by the common trends followed by the total analysed masses of each category of organic molecules (Figs. 1b, 2a, $3 \mathrm{c})$. However, these trends remain partly unexplained. Whereas the trends observed during the first week of the fossilisation can be linked to lysis of the $M$. jannaschii cells and the formation of the silica precipitate (see below), the peak observed after two months (Figs. 1b, 2a, 3c) cannot be related to a process that occurred during the experimental fossilisation: after the precipitation of silica and the cell lysis, a steady-state was observed during the fossilisation beyond 1 month with the only process observed being the continuous compaction of the silica precipitate (Orange et al. 2009). It may be due to an experimental artifact due to sampling or lyophilisation.

In this study we focused on a global analysis of compound families. As a consequence, the results provide no information regarding the origin of the analysed compounds (cytoplasm, cell wall, EPS) nor can we differentiate between molecules involved in polymers, those present in the free state in the medium, or those originating from the degradation of larger compounds during fossilisation. However, similarities between the initial and final compositions in AAs and FAs (Figs. 1h, 3h) suggest that there was only limited loss of monomeric compounds 
from the organic macromolecules preserved in the silica precipitate. However, it may have affected the monosaccharides, which are likely the most reactive among the analysed compounds because of their carbonyl functional group.

\section{OM composition of a M. jannaschii culture}

Apart from monitoring changes in the OM during the experimental fossilisation of $M$. jannaschii, this study also provides information regarding the AA, monosaccharide and FA composition of a fresh $M$. jannaschii culture.

Previous proteomic studies of the AA composition of hyperthermophilic Archaea and Methano(caldo)coccales show ubiquitous higher amounts of charged AAs (Asp, Glu, His, Lys, Arg) in comparison with their mesophilic counterparts (Cambilleau and Claverie 2000; Das and Gernstein 2000; Haney et al. 1999; McDonald et al. 1999; Chakravarty and Varadarajan 2000). The charged AAs allow better stability of the protein in a high temperature environment. In addition, archaeal S-Layer proteins, in particular, are characterised by large quantities of non polar AAs (Ala, Ile, Leu, Val, Phe, Pro) (Akça et al. 2002; Claus et al. 2002; Eichler 2003). High amounts of charged and non-polar AAs were observed in the composition of M. jannaschii "cell" fraction (Fig. 1a ; Table 1) along with a lower dicarboxylic AAs content in the "EPS" fraction. The S-Layer and EPS were also identified as the most likely to have been preserved at the end of the experimental fossilisation (Orange et al. 2009) and as primary silica binding sites during the fossilisation process. If low dicarboxylic AAs amounts can be considered as characteristic of EPS during the subsequent monitoring of the fossilisation, nonpolar AAs cannot be used as specific markers of the S-Layer (i.e. markers of cell remains) as they are also found in important amounts in the "EPS" fraction (Fig. 1a).

Monosaccharide analysis of the M. jannaschii culture identified two major components, glucose and mannose, and also small quantities of allose and galactose that could not be monitored during fossilisation (Table 1). Previous reports of monosaccharide composition of archaeal EPS (Rinker and Kelly 1996; Sowers and Gunsalus 1988; Antón et al. 1988; LaPaglia and Hartzell 1997; Poli et al. 2010; Hall-Stoodley et al. 2005; Schopf et al. 2008) have mainly shown the great compositional diversity among them, including some methanogenic 
Archaea: only mannose for Thermococcus littoralis (Rinker et al. 1996), mainly mannose for Haloferax mediterranei (Antón et al. 1988), a mixture of rhamnose, mannose, galactose and glucose for Methanobacterium formicium (LaPaglia and Hartzell 1997), galactose and glucosamine for Methanosarcina mazeii (LaPaglia and Hartzell 1997). Our results confirm this diversity.

Most of the literature concerning archaeal lipids deals with their specific membrane lipids (which were not analysed in this study; see review in Patel and Sprott 2006). Archaea and Bacteria are distinguished by the composition of their cell envelopes. While the bacterial membrane is made of diacyl-D-glycerol diesters, the archaeal membrane consists of isoprenoid L-glycerol diethers or diL-glycerol tetraethers with long isoprenoid chains containing 20-40 carbon atoms (Kandler and König, 1998). Consequently, polar lipid FAs (PLFA) have thus been used as a marker of the presence of Bacterial and Eukaryotic biomass, while the presence of isoprenoid diether/tetraether is considered as indicative of the presence of Archaea (Jeanthon 2000). However, FAs were also identified in Archaea as a minor part of the total lipid fraction (Tornabene et al. 1978; Tornabene and Langworthy 1979; Nishihira et al. 2000; Carballeira et al. 1997). The FA composition of $M$. jannaschii shows similarities with the composition of the Archaea Pyrococcus furiosus (Carballeira et al. 1997), which has a similar range of FAs (M. jannaschii : $n-\mathrm{C}_{12: 0}$ to $n-\mathrm{C}_{30: 0} ;$ P. furiosus : $n-\mathrm{C}_{12: 0}$ to $n-\mathrm{C}_{26: 0}$ ), an even over odd carbon number compound predominance, and with $n-\mathrm{C}_{16: 0}$ and $n$ $\mathrm{C}_{18: 0}$ as the major compounds. However, in our case, all the FAs analysed were saturated, while the amount of monounsaturated FAs in P. furiosus is large.

\section{General effects of the fossilisation on the OM}

Electron microscopy observation of $M$. jannaschii fossilisation (Orange et al. 2009) showed that, while the EPS were preserved, most $M$. jannaschii cells lysed quickly and only a few badly damaged cells and cell remains could be observed after one year of fossilisation. In contrast to these morphological changes, the identity of the AA composition of the silica precipitate after one year of fossilisation with that of the fresh M. jannaschii culture (Fig. 1h) provides strong evidence that all the AAs were preserved, without any selectivity either for those more abundant in the EPS (Val, Leu, Ile, Pro, Phe) or for those in the cells 
(dicarboxylic AAs: Asp, Glu) (Fig. 1a). Thus, the OM preserved by silica after one year of fossilisation appears not to be restricted to EPS, but also most probably includes the remains of degraded $M$. jannaschii cells. This thus differs from conclusions drawn from electron microscopy monitoring which had suggested that the preservation of cell remains in general was very limited (Orange et al., 2009). It is more difficult to establish the preservation of the FAs due to the two extraction methods used. However, similarities between the fresh culture and one year FA compositions (acid hydrolysis; Fig. 3h) suggest that these constituents were also very well preserved. On the other hand, the monosaccharides were significantly degraded during fossilisation (Fig. 2a; Fig. 4).

Consequently, as AAs were the most abundant and also the best preserved compounds over the duration of this experimental fossilisation (Fig. 4), we mainly base the following discussion on them, with the results from the others compounds being used as a complement.

\section{OM behaviour during experimental fossilisation}

The similarity between initial and final AA compositions are all the more surprising since important variations in the total analysed masses and in individual organic components were observed during fossilisation.

The first major changes in organic molecule composition were noticed during the first 24 hours of the experimental fossilisation, with a ubiquitous increase of the total analysed masses (Figs. 1b, 2a, 3c). Shortly after being injected in the $M$. jannaschii media, the polymerisation of silica led to the formation of a silica precipitate within a few hours. The formation of this precipitate is slightly faster in the cell containing samples than in control samples (without cells) (as observed in Orange et al. 2009), as dissolved EPS provide a good passive support for silica nucleation (Westall et al. 2000; Handley et al. 2008). These EPS could thus have been dragged to the bottom of the flasks with the silica precipitate, thus increasing the total analysed masses of OM. This hypothesis was verified by SEM observation of smooth EPS within the silica precipitate formed after injection of silica in a M. jannaschii culture growth medium whose cells had been removed (Figs. 5a, 5b). The increases in the AA amounts analysed after 24 hours could also be attributed to an EPS production by 
M. jannaschii cells as a stress reaction to the injection of the silica solution. EPS production is one of the protective mechanisms used by microorganisms facing environmental challenges and has been demonstrated as a stress reaction of $M$. jannaschii (LaPaglia and Hartzell 1997; Johnson et al. 2005) and also during the experimental fossilisation of S. azorense (Lalonde et al. 2005). EPS precipitation and production hypotheses are both consistent with previous electron microscopy observations (Orange et al. 2009). Consequently, the AA composition after 24 hours would be expected to be richer in AAs preferentially present in the "EPS" fraction (Val, Leu, Ile, Pro, Phe, Met) and poorer in AAs specific to the "cell" fraction (dicaboxylic AAs: Asp, Glu) (Fig. 1a). A depletion of dicarboxylic AAs (Asp, Glu) was indeed noticed, but no significant enrichment in EPS-specific AAs (Val, Leu, Ile, Pro, Phe) could be seen (Figs. 1c, 1e). It was not possible to verify this hypothesis from the FA analysis, as "cell" and "EPS" fractions showed no major differences (Fig. 3b).

Individual compound proportions between 24 hours and 1 month often evolved in the opposite way than during the first 24 hours. Molecules which became more abundant in the first 24 hours usually became depleted afterwards, for example, lysine and histidine for the AAs (Fig. 1c), glucose for the monosaccharides (Fig. 2b), $n-\mathrm{C}_{18: 0}$ for the FAs (Fig. 3e). The behavior of aspartic acid, glutamine, glycine (Figs. 1c, 1e) and mannose (Fig. 2b) was the opposite. This suggests that the EPS precipitated or secreted during the first 24 hours were eventually released out of the silica precipitate due to compaction soon afterwards. As for a squeezed sponge, the observed compaction of the precipitate could have released organic molecules in the medium.

As previously mentioned, between one month and one year, a steady-state was reached with no significant changes being noticed by electron microscopy observation (see Orange et al. 2009). As most M. jannaschii cells had already lysed, no OM could have been produced. Accordingly, except for a limited number of individual organic molecules such as lysine or proline, the proportions of the individual compounds showed no significant evolution (Figs. 1c, 1d, 1e, 1f, $2 b, 3 e)$.

After one year of experimental fossilisation, in addition to the silica precipitate, significant amounts of OM were still present in the medium, as shown 
by separate analyses made in this medium (Table 1; Figs. 1g, 3f). Several facts suggest that this material mainly originates from EPS, either dissolved in the medium, or released from the compacting silica precipitate. The AA composition of the medium shows similarities with the "EPS" fraction composition, being richer in neutral AAs (Gly, Ala, Val), and poorer in dicarboxylic AAs (Asp, Glu) in comparison with the composition of the precipitate (Fig. 1g).

\section{Role of silica in the preservation of the OM}

All the above observations suggest that $\mathrm{OM}$ was preserved over the experimental period of a year at a macromolecular (e.g. peptide, protein) or cellular level (EPS, membrane, S-Layer remains) rather than as monomers (individual AAs, FAs). The preservation of the OM during the experimental fossilisation was thus not related to a particular affinity between individual organic compounds and silica. In addition, since the degradation of the $\mathrm{OM}$ in culture bottles kept sealed and under anaerobic conditions must have been limited, silica is probably also not directly responsible for the preservation of the OM after one year of fossilisation.

However, by acting as a passive support for silica nucleation and polymerisation, cells and EPS contained in the medium found themselves quickly bound to or trapped in the silica precipitate that formed within a few hours after silica injection, as exemplified by the trapping of cell remains and EPS in the silica precipitate (Orange et al. 2009). In natural conditions, this silica matrix could then be able to provide a physical protection to organic compounds throughout its continuous compaction, thus limiting microbial or chemical degradation (Mongenot et al. 2001). For example, proteins and carbohydrates are known to show a high sensitivity to diagenetic degradation and are not expected to be preserved over geological time scale (de Leeuw and Largeau 1993; Vandenbroucke and Largeau 2007), as opposed to lipids. However, several studies have reported the preservation of proteinaceous material and saccharides in kerogens or sediments (Tertiary to Jurassic sediments, Moers et al. 1994; Holocene microbialites, Camoin et al. 1999; 140 Ma Kashpir oil shale, Mongenot et al. 2001; Cretaceous microbialites, Neuweiler et al. 2002; Late Jurrassic kerogen, Riboulleau et al. 2002; 4 Ma Pula kerogen, Nguyen and Harvey 2003, 
and references therein), as the result of resistance of some molecules to degradation (de Leeuw and Largeau 1993; Moers et al. 1994; Tanoue et al., 1996), the formation of resistant macromolecules through condensation (Mongenot et al. 2001), or, more importantly, by immobilisation by fixation to minerals (Mayer 1994; Hedges and Keil 1995; Salmon et al. 1998; Six et al. 2002) or the encapsulation of these molecules in refractory organic substances (Nguyen and Harvey 1998, 2001, 2003; Knicker and Hatcher, 1997, 2001; Zang et al. 2000; Mongenot et al. 2001). Thus, in a similar way, silica precipitation probably stabilised and immobilised the OM through silica binding. Preservation of OM has been reported in silica sinters forming around hot springs. These sinters are formed as the result of the precipitation of silica, forming deposits of increasing thickness, and fossilising and entombing the microbial communities that thrive there. Preserved lipids that could be linked to the original microorganisms (Bacteria and Archaea) have recently been identified within these sinters (Pancost et al. 2005, 2006; Kaur et al. 2008). Our results suggest that proteinaceous compounds may also be found in recently formed sinters. However, entombment in a silica precipitate does not always prevent modifications at a cellular structural level (e.g. cell lysis, as demonstrated by the species M. janaschii used in this experiment), or the degradation of highly reactive compounds (such as monosaccharides), or a possible recombination between primary organic molecules (e.g. reaction between AAs and monosaccharides, Maillard 1916).

The objective of the characterisation of OM contained in sediments and rocks is to try to identify the type of original microorganism through specific biomarkers. Previous fossilisation studies have shown that the earliest steps in fossilisation are crucial for the long term preservation of morphological and molecular traces. Our results show that, although it is no longer possible to identify M. jannaschii remains as Archaea using morphological features (e.g. cell wall structure) after one year of experimental fossilisation, it was possible to identify molecular traces that still retained information related to the molecular characteristics of Archaea. AAs and FAs, and likely membrane lipids as well, were well preserved during this first step of the fossilisation and still present characteristics of (hyper)thermophilic Archaea after one year of fossilisation, such as specific AA composition (high content in charged AAs, specific of hyperthermophilic Archaea, or in non polar AAs, from archaeal S-Layer, Fig. 1h) 
or specific archaeal membranes lipids (di- or tetraethers linked to long isoprenoid chains) (Cambilleau and Claverie 2000; Das and Gernstein 2000; Haney et al. 1999; McDonald et al. 1999; Chakravarty and Varadarajan 2000; Akça et al. 2002; Claus et al. 2002; Eichler 2003; Kandler and König, 1998; Jeanthon 2000).

The aforementioned authors who studied the long term preservation of supposedly labile components have also highlighted important differences in the preservation potential of the different organic compounds (see review in de Leeuw and Laugeau 1993) and the importance for preservation of favourable environmental conditions (Poinar and Stankiewicz, 1999). This has also been shown by in situ and experimental fossilisation studies (e.g. Westall et al. 1995; Westall 1997; Toporski et al. 2002; Orange et al. 2009). The latter studies also documented the importance of rapid fossilisation to ensure good preservation of the morphological and molecular traces (e.g. Knoll et al. 1988; Bartley 1996; Schultze-Lam et al. 1995 ; Toporski et al. 2002; Konhauser et al. 2004; Orange et al. 2009). The results of our present study do not allow forecasting of the long term preservation potential of the organic compounds still present after one year of fossilisation. We have not simulated the long and complex diagenetic processes which degrade and transform the OM. However, by providing knowledge on the behaviour of the OM during the first steps of the fossilisation, this study helps to decipher some of the complex processes that took place immediately after the death of the organisms and during the beginning of the fossilisation, which are crucial for allowing the eventual preservation of $\mathrm{OM}$ in kerogens or sediments.

\section{Conclusions}

Monitoring of the fate of organic matter during the fossilisation of $M$. jannaschii over the period of a year has provided new information that helps to better assess the mechanisms that take place during fossilisation and the fate of OM during its initial degradation.

With AAs and FAs being the best preserved compounds over the duration of the experimental fossilisation, analyses showed that silica precipitation led to a 
uniform and global preservation of the OM, with no distinction between the different microbial products (EPS or cells). This observation is particularly noteworthy because the $M$. jannaschii cells themselves were not well preserved. Furthermore, our analyses also provided new information concerning the chronology of EPS fossilisation, showing that their preservation was likely due to a very rapid association (within 24 hours) between polymerising silica and EPS dissolved in the medium, leading eventually to the precipitation of silica and EPS. Silica clearly played an important role in the preservation of the OM by stabilising it and providing physical protection against possible degrading agents.

This study thus provides new methods and ideas for the detection and the identification of OM during the fossilisation, which could be applied to fossilised remains of microorganisms in soil and in both ancient and recent geothermal formations.

\section{Acknowledgements}

This study was financially supported by the CNRS and CNES. The authors would like to warmly thank Annie Richard for technical assistance with the electronic microscopy, and the two anonymous reviewers for their helpful comments on this manuscript.

\section{References}

Akça E, Claus H, Schultz N, Karbach G, Schlott B, Debaerdemaeker T, Declercq JP, König H (2002) Genes and derived amino acid sequences of S-Layer proteins from mesophilic, thermophilic, and extremely thermophilic methanococci. Extremophiles 6:351-358. doi: 10.1007/s00792-001-0264-1

Allwood AC, Walter MR, Kamber BS, Marshall CP, Burch IW (2006) Stromatolite reef from the Early Archaean era of Australia. Nature 441:714-718. doi:10.1038/nature04764 
Allwood AC, Grotzinger JP, Knoll AH, Burch IW, Andreson MS, Colemans ML, Kanik I (2009)

Controls on development and diversity of Early Archaean stromatolites. P Natl Acad Sci USA 106:9548-9555. doi: 10.1073/pnas.0903323106

Antón J, Meseguer I, Rodríguez-Valera F (1988) Production of an extracellular polysaccharide by Haloferax mediterranei. Appl Environ Microb 54:2381-2386

Balch WE, Wolfe RS (1976) New approach to the cultivation of methanogenic bacteria: 2mercaptoethanesulfonic acid (HS-CoM)-dependent growth of Methanobacterium ruminantium in a pressurized atmosphere. Appl Environ Microb 32:781-791

Bartley JK (1996) Actualistic taphonomy of cyanobacteria: Implications for the Precambrian fossil record. Palaios 11:571-586

Benning LG, Phoenix VR, Yee N, Tobin MJ (2004a) Molecular characterization of cyanobacterial silicification using synchrotron infrared micro-spectroscopy. Geochim Cosmochim Ac 68:729741. doi: 10.1016/S0016-7037(03)00489-7

Benning LG, Phoenix VR, Yee N, Konhauser KO (2004b) The dynamics of cyanobacterial silicification: an infrared micro-spectroscopic investigation. Geochim Cosmochim Ac 68:743-757. doi: 10.1016/S0016-7037(03)00488-5

Bethge O, Holmström C, Juhlin S (1966) Quantitative gas chromatography of mixtures of simple sugar. Svenk Papperstidning 69:60-63.

Birnbaum SJ, Wireman JW, Borowski R (1989) Silica precipitation by the anaerobic sulphate reducing bacterium Desulfovibrio desulfuricans: effects upon cell morphology and implications for preservation. In: Crick RE (ed) Origin, Evolution, and Modern Aspects of Biomineralization in Plants and Animals. Plenum Press, New York, USA, pp. 507-516

Brasier MD, Green OR, Jephcoat AP, Kleppe AK, Van Kranendonk MJ, Lindsay JF, Steele A, Grassineau NV (2002) Questioning the evidence for Earth's oldest fosils. Nature 416:76-81. doi:10.1038/416076a

Brocks JJ, Pearson A (2005) Building the biomarker tree of life. Rev Mineral Geochem 59:233258. doi: $10.2138 / \mathrm{rmg} .2005 .59 .10$

Brocks JJ (2011) Millimeter-scale concentration gradients of hydrocarbons in Archean shales: Live-oil escape or fingerprint of contamination? Geochim Cosmochim Ac 75:3196-3213 
Cambilleau C, Claverie JM (2000) Structural and genomic correlates of hyperthermostability. J Biol Chemistry 275:32383-32386. doi: 10.1074/jbc.C000497200

Camoin G, Gautret P, Montaggioni L, Cabioch G (1999) Nature and environmental significance of microbialites in Quaternary reefs: the Tahiti paradox. Sediment Geol 126:271-304. doi: 10.1016/S0037-0738(99)00045-7

Carballeira NM, Reyes M, Sostre A, Huang H, Verhagen MF, Adams MW (1997) Unusual fatty acid compositions of the hyperthermophilic Archaeon Pyrococcus furiosus and the Bacterium Thermotoga maritima. J Bacteriol 179:2766-2768

Chakravarty S, Varadarajan R (2000). Elucidation of determinants of protein stability through genome sequence analysis. FEBS Lett 470:65-69. doi:10.1016/S0014-5793(00)01267-9

Claus H, Akça E, Debaerdemaeker T, Evrard C, Declercq JP, König H (2002) Primary structure of selected archaeal mesophilic and extremely thermophilic outer surface layer proteins. Syst Appl Microbiol 25:3-12. doi:10.1078/0723-2020-00100

Comont L, Laggoun-Défarge F.,Disnar JR (2006) Evolution of organic matter indicators in response tomajor environmental changes: the case of a formerly cut-over peat bog (Le Russey, Jura Mountains, France). Org Geochem 37:1736-1751. doi: 10.1016/j.orggeochem.2006.08.005

Das R, Gerstein M (2000) The stability of thermophilic proteins: a study based on comprehensive genome comparison. Funct Integr Genomic 1:76-88. doi: 10.1007/s101420050009

Decho AW, Visscher PT, Reid RP (2005) Production and cycling of natural microbial exopolymers (EPS) within a marine stromatolite. Palaeogeogr Palaeocl 219:71-86. doi:10.1016/j.palaeo.2004.10.015

de Leeuw, J.W., Largeau, C., 1993. A review of macromolecular compounds that comprise living organisms and their role in kerogen, coal and petroleum formation. In Engel MH, Macko SA (eds) Organic Geochemistry - Principles and Applications. Plenum Press, New York, USA, pp. 23-72.

Disnar JR, Jacob J, Morched-Issa M, Lottier N, Arnaud F (2008) Assessment of peat quality by molecular and bulk geochemical analysis; application to the Holocene record of the Chautagne marsh (Haute Savoie, France). Chem Geol 254:101-112. doi:10.1016/j.chemgeo.2008.06.004

Eichler J (2003) Facing extremes: archaeal surface-layer (glyco)proteins. Microbiology 149:33473351. doi: 10.1099/mic.0.26591-0 
Ferris FG, Fyfe WS, Beveridge TJ (1988) Metallic ion binding by Bacillus subtilis: implications for the fossilization of microorganisms. Geology, 16, 149-152.

Francis S, Margulis L, Barghoorn ES (1978) On the experimental silicification of microorganisms. II. On the time of appearance of eukaryotic organisms in the fossil record. Precambrian Res 6:65100.

Gautret P, Trichet J (2005) Automicrites in modern cyanobacterial stromatolitic deposits of Rangiroa, Tuamotu Archipelago, French Polynesia: biogeochemical parameters underlaying their formation. Sediment Geol 178:55-73. doi:10.1016/j.sedgeo.2005.03.012

Hall-Stoodley L, Costerton JW, Stoodley P (2005) Bacterial biofilms: from the natural environment to infectious diseases. Nat Rev Microbiol 2:95-108. doi:10.1038/nrmicro821

Handley KM, Turner SJ, Campbell KA, Mountain BW (2008) Silicifying biofilm exopolymers on a hot-spring microstromatolite: templating nanometer-thick laminae. Astrobiology 8:747-770. doi:10.1089/ast.2007.0172

Haney PJ, Badger JH, Buldak GL, Reich CI, Woese CR, Olsen CR (1999) Thermal adaptation analyzed by comparison of protein sequences from mesophilic and extremely thermophilic Methanococcus species. P Natl Acad Sci USA 96:3578-3583. doi: 10.1073/pnas.96.7.3578

Hedges JI, Keil RG (1995) Sedimentary organic matter preservation: an assessment and speculative synthesis. Mar Chem 49:81-115. doi:10.1016/0304-4203(95)00008-F

Jeanthon C (2000) Molecular ecology of hydrothermal vent microbial communities. Antonie van Leeuwenhoek, 77, 117-133. doi: 10.1023/A:1002463825025

Johnson MR, Montero CI, Conners SB, Schockley KR, Bridger SL, Kelly RM (2005) Population density-dependent regulation of exopolysaccharide formation in the hyperthermophilic bacterium Thermotoga maritima. Mol Microbiol 55:664-674. doi: 10.1111/j.1365-2958.2004.04419.x

Jones WJ, Leigh JA, Mayer F, Woese CR, Wolfe RS (1983) Methanococcus jannaschii sp. nov., an extremely thermophilic methanogen from a submarine hydrothermal vent. Arch Microbiol 136:254-261. doi: 10.1007/BF00425213

Kandler O, König H (1998) Cell wall polymers in Archaea (Archaebacteria). Cell Mol Life Sci 54:305-308. doi: 10.1007/s000180050156 
Kaur G, Mountain BW, Pancost RD (2008) Microbial membrane lipids in active and inactive sinters from Champagne Pool, New Zealand: Elucidating past geothermal chemistry and microbiology. Org Geochem 39:1024-1028 doi:10.1016/j.orggeochem.2008.04.016

Klock JH, Wieland A, Seifert R, Michaelis W (2007) Extracellular polymeric substances (EPS) from cyanobacterial mats: characterisation and isolation method optimisation. Mar Biol 152:10771085. doi: 10.1007/s00227-007-0754-5

Knicker H, Hatcher PG (1997) Survival of protein in an organic-rich sediment: possible protection by encapsulation in organic matter. Naturwissenschaften 84:231-234. doi:

$10.1007 / \mathrm{s} 001140050384$

Knicker H, Hatcher PG (2001) Sequestration of organic nitrogen in the sapropel from Mangrovre Lake, Bermuda. Org Geochem 32, 733-744. doi: 10.1016/S0146-6380(01)00005-5

Knoll AH, Strother PK, Rossi S (1988) Distribution and diagenesis of microfossils from the Lower Proterozoic Duck Creek Dolomite, Western Australia. Precamb Res 38:257-279. doi:10.1016/0301-9268(88)90005-8

Konhauser KO, Jones B, Phoenix VR, Ferris G, Renaut RW (2004) The microbial role in hot spring silicification. Ambio 33:552-558. doi : 10.1579/0044-7447-33.8.552

Lalonde SV, Konhauser KO, Reysenbach AL, Ferris FG (2005) The experimental silicification of Aquificales and their role in hot spring formation. Geobiology 3:41-52. doi:10.1111/j.1472-

4669.2005.00042.x

LaPaglia C, Hartzell PL (1997) Stress-induced production of biofilm in the hyperthermophile Archaeoglobus fulgidus. Appl Environ Microbiol 63:3158-3163

Maillard LC (1916) Synthèse des matières humiques par action des acides aminés sur les sucres réducteurs. Annales de Chimie, $9^{\text {ème }}$ série, 5:258-317.

Mayer LM (1994) Relationships between mineral surfaces and organic carbon concentrations in soils and sediments. Chem Geol 114:347-363. doi.org/10.1016/0009-2541(94)90063-9

McDonald JH, Grasso AM, Rejto LK (1999) Patterns of temperature adaptation in proteins from Methanococcus and Bacillus. Mol Biol Evol, 16:1785-1790

Moers MEC, de Leeuw JW, Baas M (1994) Origin and diagenesis of carbohydrates in ancient sediments. Org Geochem 21:1093-1106. doi: 10.1016/0146-6380(94)90072-8 
Mojzsis SJ, Arrheinius G, McKeegan KD, Harrison TM, Nutman AP, Friend RL (1996) Evidence for life on Earth before 3.800 million years ago. Nature 384:55-59. doi:10.1038/384055a0

Mongenot T, Riboulleau A, Garcette-Lepecq A, Derenne S, Pouet Y, Baudin F, Largeau C (2001) Occurrence of proteinaceous moieties in S- and O-rich Late Tithonian kerogen (Kashpir oil shales, Russia). Org Geochem 32:199-203. doi: 10.1016/S0146-6380(00)00154-6

Neuweiler F, Gautret P, Thiel V, Lange R, Michaelis W, Reitner J (2002) Petrology of Lower Cretaceous carbonate mud mounds (Albian, N. Spain): insights into organomineralic deposits of the geological record. Sedimentology 46: 837-859. doi: 10.1046/j.1365-3091.1999.00255.x

Nguyen RT, Harvey HR (1998) Protein preservation during early diagenesis in marine waters and sediments. In Stankiewicz BA, van Bergen PF (eds.) Nitrogen-containing Macromolecules in the Bio- and Geosphere. ACS Symposium Series 707, pp. 89-112.

Nguyen RT, Harvey HR (2001) Preservation of proteins in marine systems: hydrophobic and other noncovalent associations as major stabilizing forces. Geochim Cosmochim Ac 65:1467-1480. doi : 10.1016/S0016-7037(00)00621-9

Nguyen RT, Rodger Harvey H (2003) Preservation via macromolecular associations during Botryococcus braunii decay: proteins in the Pula Kerogen. Org Geochem 34:1391-1403. doi:10.1016/S0146-6380(02)00261-9

Nishihira M, Nagahama S, Ohga M, Koga Y (2000) Straight-chain fatty alcohols in the hyperthermophilic archaeon Pyrococcus furiosus. Extremophiles 4:275-277. doi: $10.1007 / \mathrm{s} 007920070013$

Oehler JH, Schopf JW (1971) Artificial microfossils: experimental studies of permineralization of blue-green algae in silica. Science 174:1229-1231.

Oehler JH (1976) Experimental studies in Precambrian paleontology: structural and chemical changes in blue-green algae during simulated fossilization in synthetic chert. The Geological Society of America Bulletin, 87, 117-129.

Ogier S, Disnar JR, Albéric P, Bourdier G (2001) Neutral carbohydrate geochemistry of particulate material (trap and core sediments) in an eutrophic lake (Aydat, France). Org Geochem 32:151-162. doi: 10.1016/S0146-6380(00)00138-8

Orange F, Westall F, Disnar JR, Prieur D, Bienvenu N, Le Romancer M, Défarge C (2009)

Experimental silicification of the extremophilic Archaea Pyrococcus abyssi and 
Methanocaldococcus jannaschii. Applications in the search for evidence of life in early Earth and extraterrestrial rocks, Geobiology 7:403-418. doi:10.1111/j.1472-4669.2009.00212.x

Orange F, Disnar JR, Westall F, Prieur D, Baillif P (2011) Metal cation binding by the hyperthermophilic microorganism, Archaea Methanocaldococcus jannaschii, and its effects on silicification. Palaeontology 54:954-964. doi: 10.1111/j.1475-4983.2011.01066.x

Pancost RD, Pressley S, Coleman JM, Benning LG, Mountain BW (2005) Lipid biomolecules in silica sinters: indicators of microbial biodiversity. Environmen Microbiol 7 :66-77. doi :

$10.1111 / j .1462-2920.2004 .00686 . x$

Pancost, R.D., Pressley, S., Coleman, J.M., Talbot, H.M., Kelly, S.P., Farrimond, P., Schouten, S., Benning, L.G., Mountain, B.W., 2006. Composition and implications of diverse lipids in New Zealand geothermal sinters. Geobiology 4, 71-92. doi: 10.1111/j.1472-4669.2006.00069.x

Patel GB, Sprott, GD (2006) Archaeal Membrane Lipids. In: ELS. John Wiley \& Sons Ltd, Chichester. http://www.els.net Accessed August 21 2011. doi: 10.1038/ngg.els.0004316

Pflug HD, Jaeschke-Boyer H (1979) Combined structural and chemical analysis of 3,800-Myr-old microfossils. Nature 280:483-486. doi:10.1038/280483a0

Phoenix VR, Adams DG, Konhauser KO (2000) Cyanobacterial viability during hydrothermal biomineralization. Chem Geol 169:329-338. doi.org/10.1016/S0009-2541(00)00212-6

Poinar HN, Stankiewicz BA (1999) Protein preservation and DNA retrieval from ancient tissues. P Natl Acad Sci USA 96:8426-8431.

Poli A, Anzelmo G, Nicolaus B (2010) Bacterial exopolysaccharides from extreme marine habitats: production, characterization and biological activities. Mar Drugs 8:1779-1802. doi:10.3390/md8061779

Riboulleau A, Mongenot T, Baudin F, Derenne S, Largeau C (2002) Factors controlling the survival of protaneiceous material in Late Tithonian kerogens (Kashpri Oil Shales, Russia). Org Geochem 33:1127-1130. doi:10.1016/S0146-6380(02)00081-5

Rinker KD, Kelly RM (1996) Growth physiology of the hyperthermophilic Archaeon Thermococcus littoralis: development of a sulfur-free defined medium, characterization of an exopolysaccharide, and evidence of biofilm formation. Appl Environ Microbiol 62:4478-4485. 
Salmon V, Derenne S, Lallier-Verges E, Largeau C, Beaudoin B (1998) Study of the role of the mineral matrix in sedimentary organic matter preservation (Cenomanian black shale, Central Italy). Mineral Magazine 62A:1312-1313.

Schopf JW (1993) Microfossils of the Early Archaean Apex Chert: new evidence of the antiquity of life. Science 260:640-646. doi:10.1126/science.260.5108.640

Schopf S, Wanner G, Rachel R, Wirth R (2008) An archaeal bi-species formed by Pyrococcus furiosus and Methanopyrus kandleri. Arch Microbiol 190:371-377. doi: 10.1007/s00203-0080371-9

Schultze-Lam S, Ferris FG, Kohnauser KO, Wiese RG (1995) In situ silicification of an Icelandic microbial mat: implications for microfossil formation. Can J Earth Sci 32:2021-2026.

Six J, Conant RT, Paul EA, Paustian K (2002) Stabilization mechanisms of soil organic matter : Implications for C-saturation of soils. Plant Soil 241:155-176. doi: 10.1023/A:1016125726789

Sowers KR, Gunsalus RP (1988) Adaptation for growth at various saline concentration by the Archaebacterium Methanosarcina thermophila. J Bacteriol 170:998-1002

Stefanova M, Disnar JR (2000) Composition and early diagenesis of fatty acids in lacustrine sediments, lake Aydat (France). Org Geochem 31:41-55. doi:10.1016/S0146-6380(99)00134-5

Tanoue E, Ishii M, Midorikawa T (1996) Discrete dissolved and particulate proteins in oceanic waters. Limnol Oceanogr 41:1334-1343.

Tice MM, Lowe DR (2004) Photosynthetic microbial mats in the 3,416-Myr-old ocean. Nature 431:522-523. doi:10.1038/nature02888

Tice MM, Lowe DR (2007) Tectonic controls on atmospheric, climatic, and biological evolution 3.5-2.4 Ga. Precamb Res 158:177-197. doi:10.1016/j.precamres.2007.04.008

Toporski JKW, Steele A, Westall F, Thomas-Keprta KL, McKay DS (2002) The simulated silicification of bacteria - new clues to the modes and timing of bacterial preservation and implications for the search for extraterrestrialmicrofossils. Astrobiology 2:21-26

Tornabene TG, Wolfe RS, Balch WE, Holzer G, Fox GE, Oro O (1978) Phytanylglycerol ethers and squalene in the archaebacterium Methanobacterium thermoautotrophicum. J Mol Evol 11:259-266. doi: 10.1007/BF01734487 
Tornabene TG, Langworthy TA (1979) Diphytanyl and dibiphytanyl glycerol ethers of methanogenic archaebacteria. Science 203:51-53. doi: 10.1126/science.758677

Underwood GJC, Paterson DM, Parkes RJ (1995) The measurement of microbial carbohydrate exopolymers from intertidal sediments. Limnol and Oceanogr 40:1243-1253.

Vandenbroucke M, Largeau C (2007) Kerogen origin, evolution and structure. Org Geochem 38:719-833 doi:10.1016/j.orggeochem.2007.01.001

van Zuilen MA, Lepland A, Arrhenius A (2002) Reassessing the evidence for the earliest traces of life. Nature 418:627-630. doi:10.1038/nature00934

Walsh MM (1992) Microfossils and possible microfossils from the Early Archean Onverwacht Group, Barberton Mountain Land, South Africa. Precamb Res 54:271-293

Walsh MM (2004) Evaluation of early Archean volcanoclastic and volcanic flow rocks as possible sites for carbonaceous fossil microbes. Astrobiology 4:429-437

Westall F (1997) The influence of cell wall composition on the fossilization of bacteria and the implications for the search for early life forms. In: Cosmovici C, Bowyer S, Werthimer D (eds) Astronomical and Biochemical Origins and the Search for Life in the Universe. Editori Compositrici, Bologna, pp. 491-504.

Westall F (2011) Early life: nature, distribution and evolution. In: Gargaud M, López-García P, Martin H (eds) Origins and evolution of life, an astrobiological perspective. Cambridge University Press, Cambridge, United-Kingdom, pp. 391-413

Westall F, Folk RL (2003) Exogenous carbonaceous microstructures in Early Archaean cherts and BIFs from the Isua greenstone belt: implications for the search for life in ancient rocks. Precamb Res 126:313-330. doi:10.1016/S0301-9268(03)00102-5

Westall F, Southam G (2006) The early record of life.. In Benn K, Mareschal JC, Condie KC (eds) Archean Geodynamics and Environments, Geophysical Monograph Series 164. American Geophysical Union, Washington, DC, pp. 283-304

Westall F, Cavalazzi B (2011) Biosignatures in rocks. In: Reitner J, Volker T (eds) Encyclopedia of Geobiology. Springer, Dordrecht, The Netherlands, pp. 189-201

Westall F, Boni L, Guerzoni E (1995) The experimental silicification of microorganisms. Paleontology, 38, 495-528. 
Westall F, Steele A, Toporski J, Walsh M, Allen C, Guidry S, McKay D, Gibson E, Chafetz H (2000) Polymeric substances and biofilms as biomarkers in terrestrial materials: implications for extraterrestrial samples. J Geophys Res 105:24511-24527. doi:10.1029/2000JE001250

Westall F, de Vries ST, Nijman W, Rouchon V, Orberger B, Pearson V, Watson J, Verchovsky A, Wright I, Rouzaud JN, Marchesini D, Severine A (2006a) The 3.466 Ga “Kitty's Gap Chert', an early Archean microbial ecosystem. Geological Society of America special paper 405:105-131. doi: $10.1130 / 2006.2405(07)$

Westall F, de Ronde CEJ, Southam G, Grassineau N, Colas M, Cockell C, Lammer H (2006b) Implication of a 3.472-3.333 Gyr-old subaerial microbial mat from the Barberton greenstone belt, South Africa for the UV environmental conditions on the early Earth. Phil Trans R Soc B 361:1857-1875. doi: 10.1098/rstb.2006.1896

Westall F, Cavalazzi B, Lemelle L, Marrocchi Y, Rouzaud JN, Simionovici A, Salomé M, Mostefaoui S, Andreazza C, Foucher F, Toporski J, Jauss A, Thiel V, Southam G, MacLean L, Wirick S, Hofmann A, Meibom A, Robert F, Défarge C (2011) Implications of in situ calcification for photosynthesis in a $\sim 3.3 \mathrm{Ga}$-old microbial biofilm from the Barberton greenstone belt, South Africa. Earth Planet Sc Lett 310:468-479. doi: 10.1016/j.epsl.2011.08.029

Wicks RJ, Moran MA, Pittman LJ, Hodson RE (1991) Carbohydrates signatures of aquatic macrophytes and their dissolved degradation products as determined by sensitive highperformance ion chromatography method. Appl Environ Microb 57:3135-3143.

Zang X, van Heemst JDH, Dria KJ, Hatcher PG (2000) Encapsulation of protein in humic acid from a histosol as an explanation for the occurrence of organic nitrogen in soil and sediment. Org Geochem 31:679-695. doi: 10.1016/S0146-6380(00)00040-1 


\section{Figures captions}
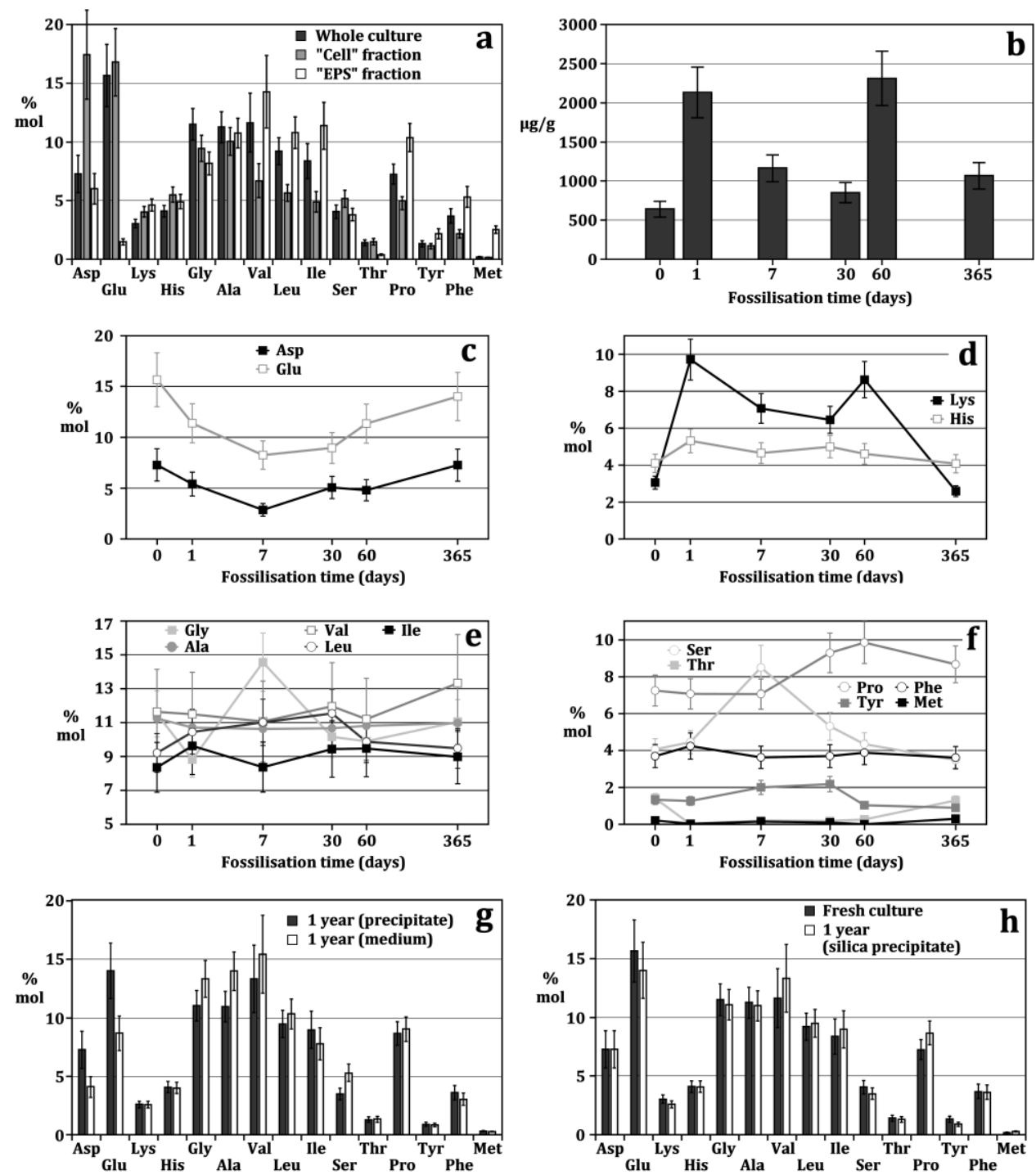

Fig. 1 Results of amino acid (AA) analyses made during the experimental fossilisation of $M$. jannaschii at a $350 \mathrm{ppm} \mathrm{Si} \mathrm{silica} \mathrm{concentration.} \mathrm{a,} \mathrm{AA} \mathrm{compositions} \mathrm{of} \mathrm{the} \mathrm{fresh} \mathrm{culture,} \mathrm{and} \mathrm{of} \mathrm{the}$ separated "cell" and "EPS" fractions; $\mathbf{b}$, total analysed masses of AA in the fresh culture and in the silica precipitate during the experimental fossilisation; c-f, evolution of individual AAs percentages during experimental fossilisation. (c, dicarboxylic AAs; d, basic AAs; e, neutral AAs; $\mathbf{f}$, aromatic and alcoholic AAs + proline); $\mathbf{g}$, AA compositions of the silica precipitate and the medium after 1 year of fossilisation; $\mathbf{h}$, comparison of AA compositions of the fresh culture and of the silica precipitate after one year of fossilisation 

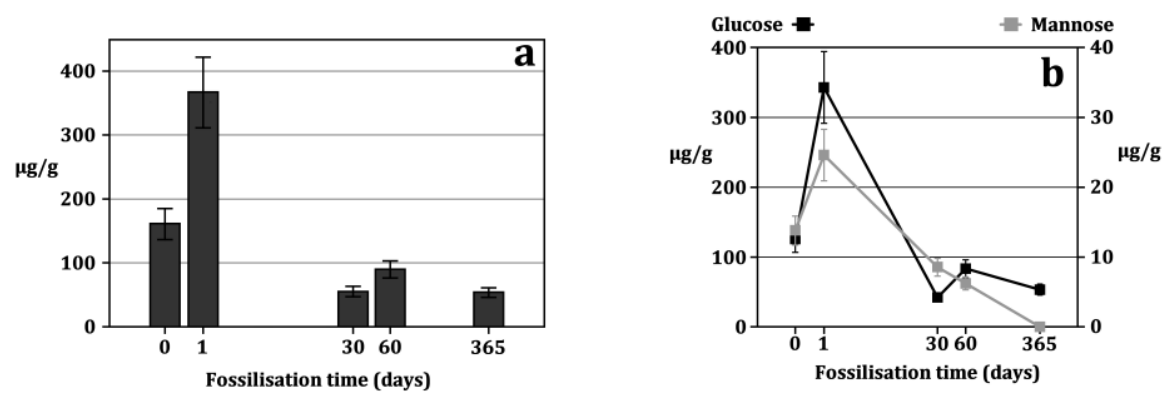

Fig. 2 Results of monosaccharide analyses made during the experimental fossilisation of $M$. jannaschii at a $350 \mathrm{ppm}$ Si silica concentration. a, total analysed masses of monosaccharides in the fresh culture and in the silica precipitate during the experimental fossilisation; $\mathbf{b}$, evolution of the analysed masses of glucose and mannose in the silica precipitate during the experimental fossilisation
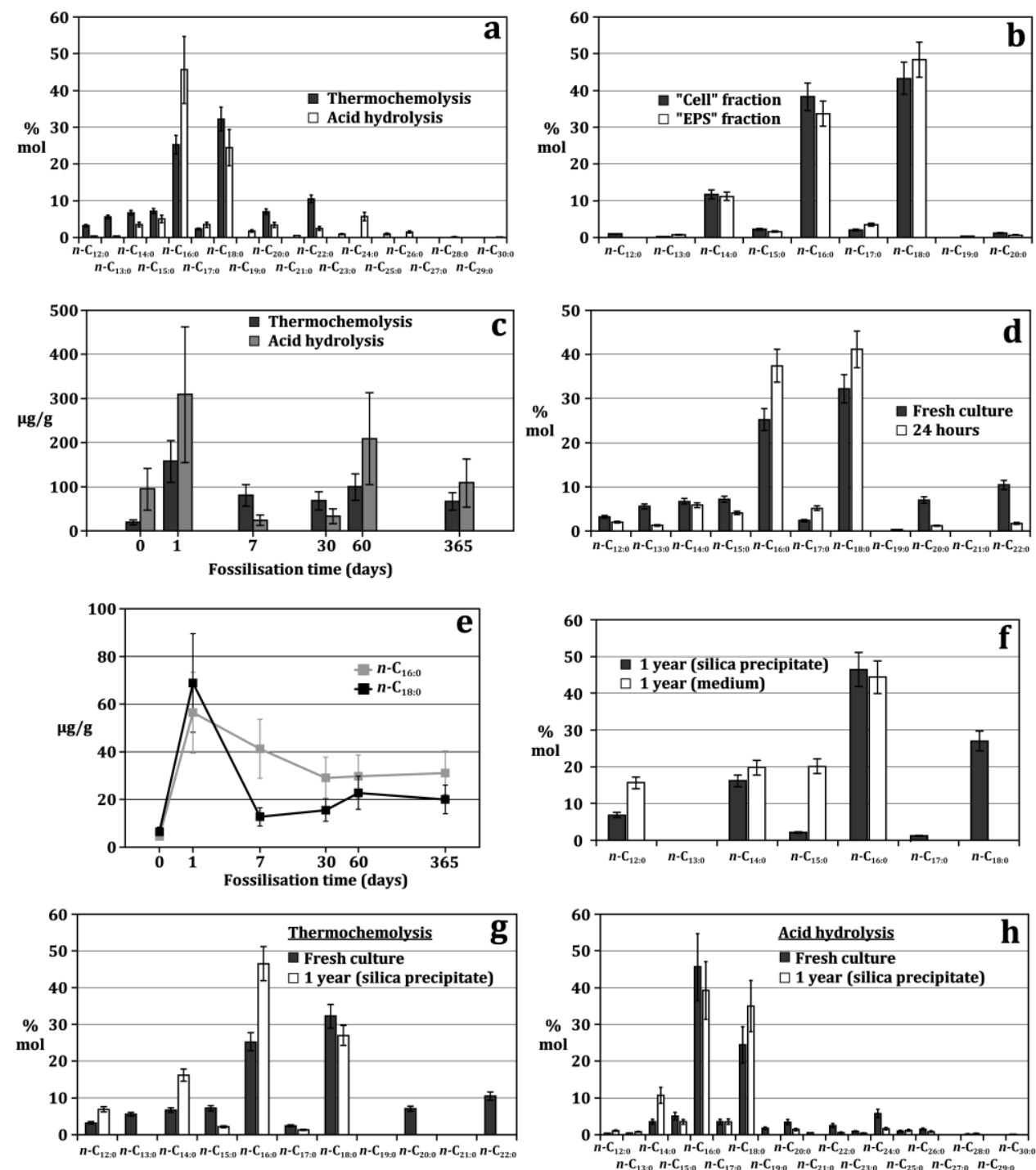

Fig. 3 Results of fatty acids (FA) analyses made during the experimental fossilisation of $M$. jannaschii at a $350 \mathrm{ppm}$ Si silica concentration. a, FA compositions of the fresh culture, obtained 
by thermochemolysis and acid hydrolysis, respectively; b, FA compositions of the separated "cell" and "EPS" fraction, obtained by thermochemolysis; c, total analysed masses of FAs in the fresh culture and in the silica precipitate during the experimental fossilisation, obtained by thermochemolysis and acid hydrolysis, respectively; d, FA composition of the fresh culture and of the silica precipitate after 24 hours of fossilisation, obtained by thermochemolysis; e, evolution of $n-\mathrm{C}_{16: 0}$ and $n-\mathrm{C}_{18: 0}$ masses in the silica precipitate during the experimental fossilisation, obtained by thermochemolysis; $\mathbf{f}$, FA compositions of the silica precipitate and the medium after 1 year of fossilisation, obtained by thermochemolysis; $\mathbf{g}, \mathbf{h}$, comparisons of FA compositions of the fresh culture and of the silica precipitate after one year of fossilisation, obtained by thermochemolysis and acid hydrolysis, respectively

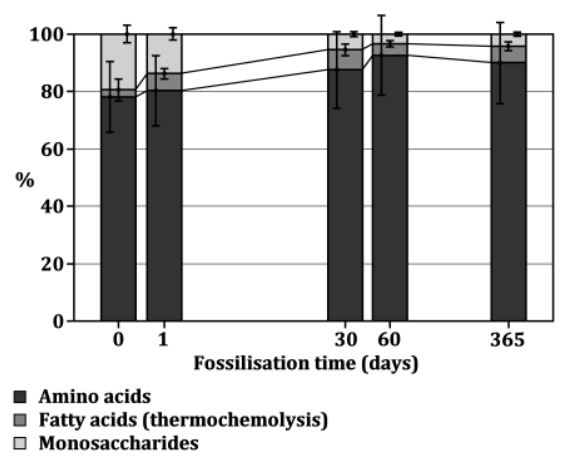

Fig. 4 Evolution of the proportions of the different kinds of organic compounds analysed during the experimental fossilisation of $M$. jannaschii; proportions were calculated from total analysed masses (Table 1). 

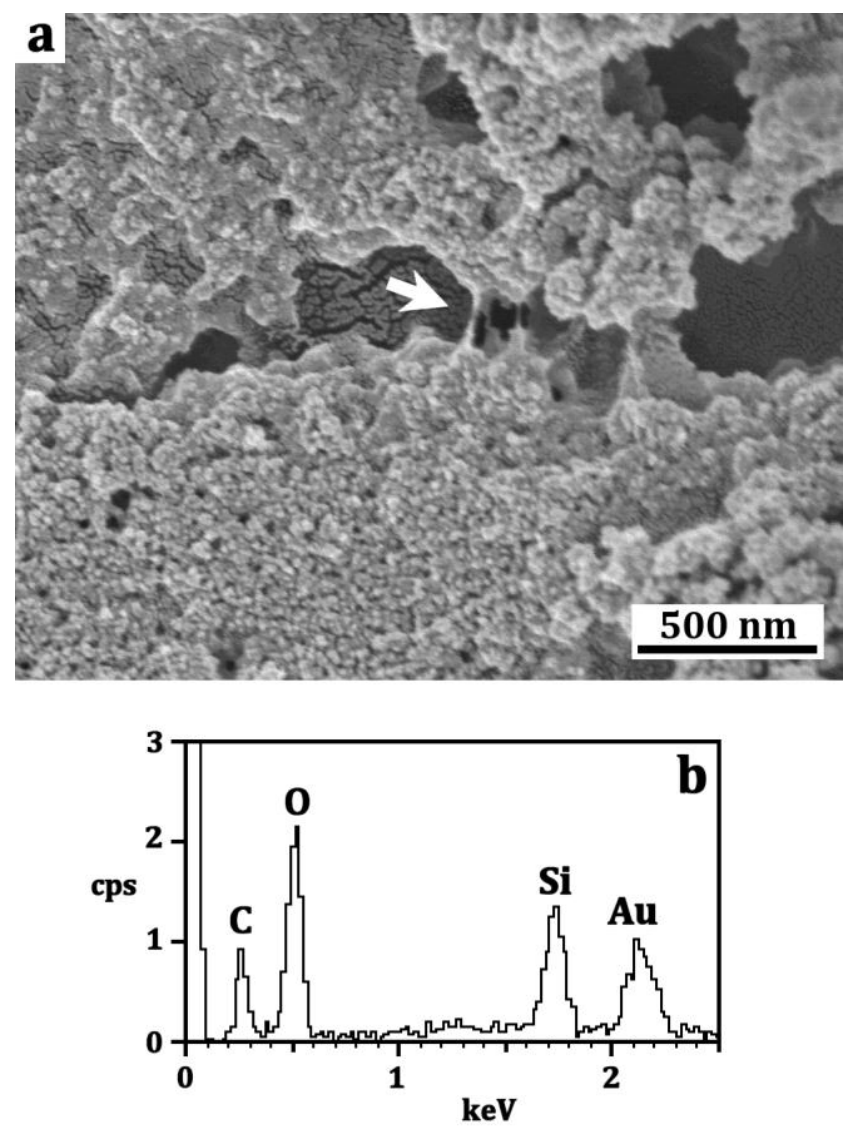

Fig. 5 Scanning electron microscopy (SEM) micrograph (a) of the silica precipitate formed after the injection of silica in a M. jannaschii growth medium after cells had been removed, with the corresponding EDX spectrum (b) made on the silica precipitate; note the smooth EPS inside the precipitate (arrow) and the carbon signal on the EDX spectrum, indicating important amounts of organic materials in the precipitate. 